\title{
BALIKA fact sheet: Highlight on girls' social lives
}

Population Council

Follow this and additional works at: https://knowledgecommons.popcouncil.org/departments_sbsr-pgy

Part of the Demography, Population, and Ecology Commons, Family, Life Course, and Society Commons, and the International Public Health Commons How does access to this work benefit you? Let us know!

\section{Recommended Citation}

"BALIKA fact sheet: Highlight on girls' social lives." New York: Population Council, 2014. 
In addition to schooling, work opportunities and family-building patterns, social networks, mobility, and civic participation are important dimensions of the lives of young people.

- Previous studies have suggested many ways in which the seclusion of Bangladeshi women by the practice of purdah exerts a strong influence on the lives of girls, starting from an early age.

- School enrollment plays a positive role by affording girls greater mobility and access to clubs and institutions, and by promoting social interactions.

- Adolescent girls in rural Bangladesh are usually socially isolated, have restricted mobility, few friends, and are vulnerable to physical, economic, and sexual abuse both inside and outside the home.

- The high prevalence of gender-based violence and the fear of experiencing GBV permeate all aspects of social life for girls.

\section{RURAL ADOLESCENT GIRLS' ACCESS TO FACILITIES AND INSTITUTIONS}

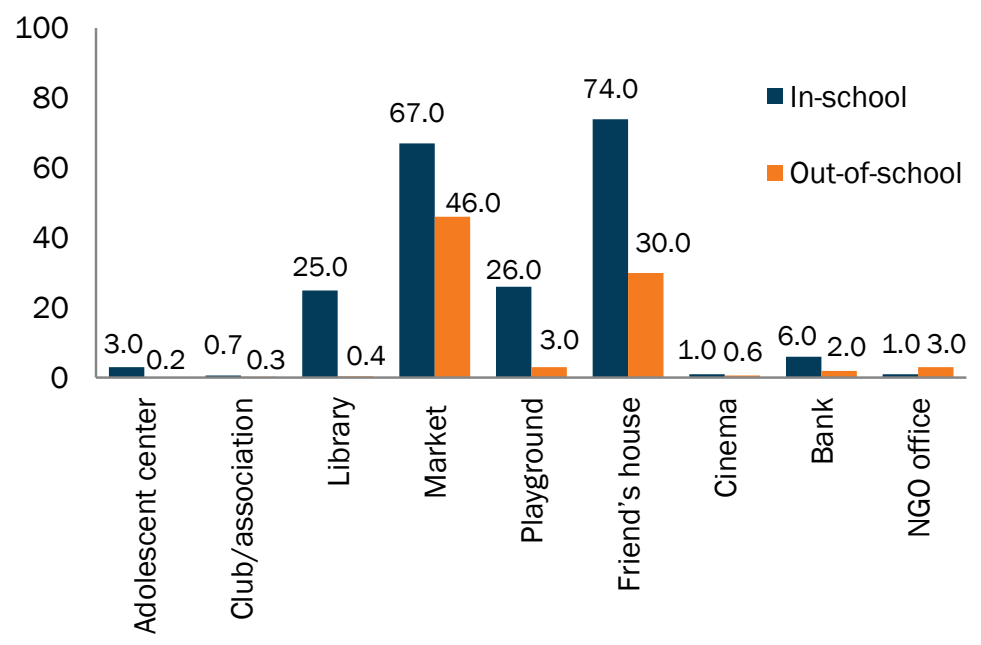

- In general the mobility of out-of-school girls is markedly more restricted than mobility of in-school girls. Girls reported mostly visiting a friend's house or going to a market, playground, or library. Only a few went to an adolescent center, club, or an NGO office.

\section{HIGHLIGHTS}

- Girls who are in school are less restricted than girls who are not in school. In addition to going to school, they are more likely to say they can go to the market and visit friends' homes compared to girls not in school.

- Opportunities for civic participation through clubs and associations are limited. Only 7 percent reported belonging to a club or organization.

- Opinions regarding rules of propriety suggest girls are conservative about their social interactions with boys. Only about one-fourth of the girls supported having friends of the opposite sex. Adolescent girls strongly believe that girls should observe purdah.

- Girls are being harassed both inside and outside the home and also in school; 11 percent of all adolescent girls said they have experienced sexual harassment at home or by a close relative.

AFFILIATION WITH DIFFERENT CLUBS/ASSOCIATIONS/GROUPS

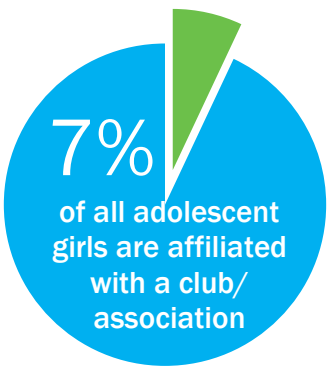




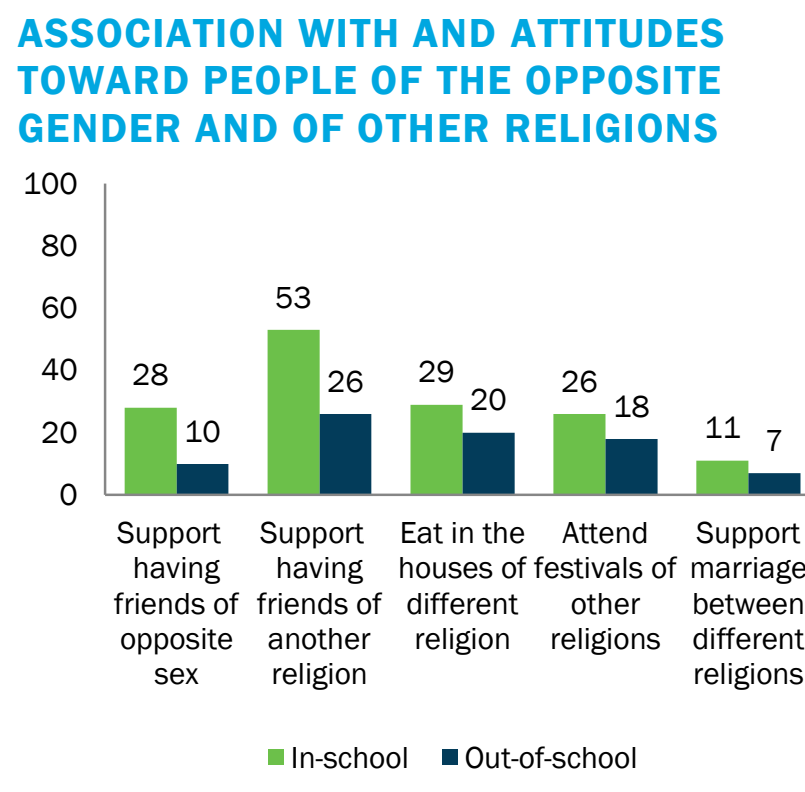

- Overall very few girls supported having friends of the opposite sex or of a different religion.

- Girls in school are more likely to be open to having friends and social interactions between boys and girls and across religious groups.

- In-school girls were considerably more likely than out-of-school girls to support having friends of the opposite sex and friends of a different religion.

- In general, ideas about social interactions were most rigid about interfaith marriage -only 11 percent of in- school girls and 7 percent of out-ofschool girls support interfaith marriages.

\section{ADOLESCENT GIRLS' OPINIONS REGARDING OBSERVANCE OF PURDAH}

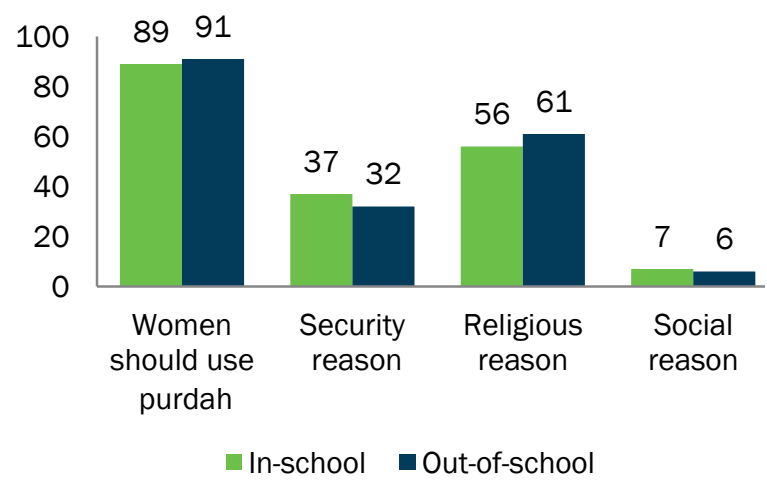

- Attitudes toward observance of purdah were measured by asking how women and girls should observe purdah outside the home. About $90 \%$ of adolescent girls believe that women should observe purdah. Religious observance and personal security were the two most common reasons given. “....when I reached about $14 / 15$ years old, my leisure activities were limited to only playing ludu (a board game). Going outside the home was not allowed. My parents would say that I had grown up and should not go out frequently as we live in a rural society."

-26-YEAR-OLD WOMAN

\section{EXPOSURE TO HARASSMENT}

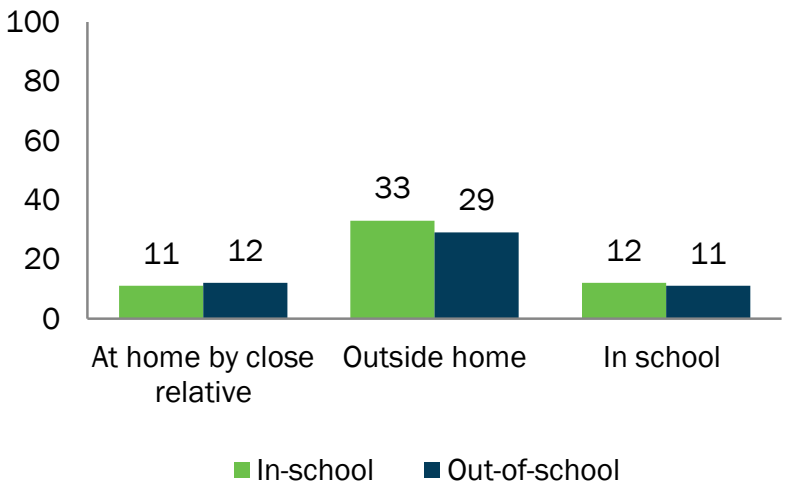

- In-school girls are more likely to experience harassment because their mobility is high relative to girls who do not go to school. The classroom is also a place of harassment for school girls.

PUBLIC SEXUAL HARASSMENT MAY LEAD TO EARLY MARRIAGE:

"...to tell you the truth... there was a boy who was after me and disturbed me. My parents were afraid that the boy might do something harmful to me so they married me off."

- 14-YEAR-OLD GIRL WHO WAS MARRIED AT THE AGE OF 12 AND HAD TO DISCONTINUE HER EDUCATION

\section{CONCLUSION}

School enrollment creates important contrasts in the social lives of adolescent girls. Compared to in-school adolescent girls, the lives of out-of-school girls are more restricted. Most of these girls are not associated with clubs/associations and do not participate in children's groups. In-school girls are more liberal in choosing friends from other religions and are more positive about interfaith marriage. More access to social/cultural associations and institutions likely increases the decision-making skills of adolescent girls regarding early marriage and other development issues. 